\title{
Organizational Commitment of High School Teachers
}

\author{
Necmi Gökyer \\ Correspondence: Assoc. Prof. Dr. Necmi Gökyer, Firat University, Faculty of Education, Educational Sciences \\ Department, Turkey.
}

Received: December 3, 2017

Accepted: January 28, 2018

Online Published: April 1, 2018

doi:10.11114/jets.v6i3a.3165

URL: https://doi.org/10.11114/jets.v6i3a.3165

\begin{abstract}
The aim of this study is to identify high school teachers' commitment to school development, colleagues, the teaching profession and sense of duty. The population of this descriptive survey comprised 2,805 teachers working at 47 high schools in Elazığ during the 2016-2017 school year. The study sample was selected through stratified sampling, which aims to identify subgroups in a population and ensure that their size in the sample represents their proportion in the population. The data collection tool was then distributed to 461 teachers working in 12 schools selected randomly from these strata. The data collection tool had two sections. The first had conceptual questions and the second had questions about organizational commitment behaviors. The results showed that high school teachers felt full commitment only to the teaching profession, while they "often" felt committed in other subdimensions and the entire scale. More precisely, the commitment level of science teachers to school development was higher than that of social sciences teachers. Teachers working in the city center had higher commitment to colleagues and school development than those in small towns. Teacher candidates had higher commitment to sense of duty than teachers and specialist teachers. Teachers working at vocational and technical high schools had lower commitment to school development than teachers working at Anatolian high schools, social sciences and science high schools. There was a moderate, negative and meaningful relationship between teachers' age, professional seniority, professional title and marital status. There was a high, positive and meaningful relationship between the subdimensions and the entire scale. Among the subdimensions, too, there was a moderate, positive and meaningful relationship.
\end{abstract}

Keywords: high school, organizational commitment, commitment to the teaching profession

\section{Introduction}

The degree to which a task is effectively carried out depends on the characteristics of the work environment. The concept of work environment is associated with the environment, organizational effectiveness, climate, ecological field, organizational ideology or organizational information (Hoy, Tarter, Kottkamp, 1991; Celep, 2000:143). The sense of work environment that teachers have, which results from the facilities available in the work environment, is significant enough to affect their styles of work. One factor which forms the foundation of teachers' sense of work environment is their interest and attitudes towards the objects in their work environment (profession, work, team, student, school). One concept that reveals the interest of workers in the objects in their work environment is organizational commitment.

As a concept and way of understanding, organizational commitment exists anywhere with a sense of community and is an emotional representation of social instincts. Embodying the loyalty of a slave to his master, of a civil servant to his duty and of a soldier to his homeland, commitment was once referred to as loyalty and refers to the state of being loyal. Overall, commitment is an ultimate feeling. Feeling committed to a person, a thought, an institution or something bigger than ourselves refers to a responsibility which we must meet (Ergun, 1975).

Organizational commitment is defined as someone's biased and effective commitment to the goals and values of an organization. More than a mere tool, this type of commitment requires an individual to play his role solely for the well-being of the organization, in relation with its goals and values. Committed workers firmly believe in the goals and values of the organization, voluntarily follow orders and expectations (Firestone and Pennell, 1943; cited in Balay, 2000). Being a work-related attitude of workers, organizational commitment is defined by Mowday et al. as "a high level of belief in and acceptance of organizational goals and values, the will to make a real effort for organizational goals; and a strong desire to stay in an organization and continue membership in it" (Mowday et al., 1979; cited in Boylu, Pelit and Güçer, 2007). Commitment is defined as "behaviors limited to one's actions or those that exceed formal, normative expectations" (Mowday, Steers, Porter, 1979; Celep, 2000:15). First coined by Lodahl and Kejner (1965), organizational commitment is 
a biased and effective commitment to organizational goals and values. More than a mere tool, this type of commitment requires an individual to play his role solely for the well-being of the organization, in relation with its goals and values (Lodahl and Kejner, 1965; Artun, 2008). Mowday et al. (1979) define organizational commitment as an individual identifying with a certain organization and the strength of his ties to it. Kanungo (1982) treats organizational commitment in two dimensions, commitment to work itself and to the organization, and defines the term as the psychological association that an individual has established with an organization.

Allen and Mayer (1991) developed a three-dimensional model by emphasizing the psychological side of organizational commitment. They explored organizational commitment in three levels: affective, continuance and normative commitment. Affective commitment is defined as the wish of workers to commit emotionally to the organization. Workers stay in the organization with their own will and desire. Continuance commitment refers to the workers to make the decision of staying in the organization by weighing the costs of leaving against the benefits of staying in the organization. Normative commitment, the final dimension, refers to a type of compulsory commitment in which workers stay in the organization owing to a sense of security and responsibility (Erdil and Keskin, 2003). Commitment to the school is defined as teachers adopting the goals and values of the school, making an effort to meet them, and sustaining their will to stay in the school. This definition is based on "organizational commitment" (Mowday, Porter, Steers, 1979, p.232; Celep, 1998:58).

In this study, teachers' organizational commitment is divided into the following subheadings: commitment to school development, commitment to colleagues, commitment to the teaching profession and commitment to an advanced sense of duty. Teachers' commitment to school development was tested with four items: "I am proud of my school; my school gives me the passion to work; I enjoy working at my school although I could work elsewhere; I feel that my school is the best." Teachers' commitment to an advanced sense of duty was tested with the following ten items: "I make a lot of effort for unsuccessful students; I would continue the teaching profession even if I didn't need the money; I am proud of being in the teaching profession; I view the teaching profession as an ideal profession; I would like to have a name in the teaching profession; I view the values of the teaching profession as superior to other professional values; choosing the teaching profession was the best decision in my life; I make time for my students outside the classroom for both course-related and other issues; I get informed about my students' family life; I would be willing to teach a course outside my subject area if that was the only way of teaching at my school". Teachers' commitment to the teaching profession was tested with the following six items: "I go to class on time; I enjoy going to class; I participate actively in school meetings; I avoid causing problems for my colleagues; I make an effort to contribute to the school's reputation; I am willing to help my colleagues solve their work-related problems". Finally, teachers' commitment to colleagues was tested with five items: "I believe other teachers at school see me as a close friend of theirs; My best friends in life are other teachers at my school; I enjoy spending time with other teachers between classes; I view myself as a close friend of other teachers at school; I maintain a relationship with other teachers outside school as well".

\section{Problem statement and sub-problems (hypotheses)}

The aim of this study is to determine high school teachers' commitment to school development, colleagues, the teaching profession and an advanced sense of duty.

The following research questions were investigated in the study:

1. What are high school teachers' organizational commitment feelings in the subdimensions and the entire scale?

2. Do high school teachers' commitment to the development of their school, their colleagues, the teaching profession and an advanced sense of duty vary depending on variables such as gender, marital status, age, professional experience, title, subject area, work place and place of duty?

3. Is there a significant relationship between the subdimensions of the organizational commitment scale and high school teachers' gender, marital status, age, professional experience, title, subject area, work place and place of duty?

\section{Method}

\subsection{Method of the Research}

This study is a survey. Surveys aim to describe a past or present situation, event, individual or object as it is, in its own conditions (Karasar, 2009:77).

\subsection{Population-Sampling}

The population included a total of 2,805 teachers working at 47 high schools located in Elazığ city center during the 2016-2017 school year. Stratified sampling, which ensures proportional representation of subgroups in the entire universe, was used in this study (Büyüköztürk, 2016:86). The data collection tool was distributed to 461 teachers working at 12 randomly selected schools from these strata. However, data from only 404 teachers were ultimately analyzed. The data collection tool had two sections. The first section comprised conceptual questions and the second 
one comprised items about teachers' organizational commitment behaviors. Sample size was determined by using the table designed by Krejcie and Morgan (1970). Accordingly, the sample size necessary for 95\% confidence level in a population of 3,000 individuals was 341 (Krejcie and Morgan, 19709:607).

The demographics of the participating teachers were as follows: $42,1 \%$ were female $(n=170), 57,9 \%$ were male $(n=234)$; $73,5 \%$ were married $(n=297), 26, \%$ were single $(n=107) ; 26,2 \%$ were aged between $21-30$ years $(n=106), 39,6 \%$ were aged between 31-40 years $(n=160), 24,5 \%$ were aged between $41-50$ years $(n=99), 9,7 \%$ were aged 51 and above $(\mathrm{n}=39) ; 19,6 \%$ had 1-2 years of work experience $(\mathrm{n}=79), 18,8 \%$ had 3-7 years of work experience $(\mathrm{n}=76), 27,2 \%$ had 8-12 years of work experience $(n=110), 14,6 \%$ had 13-17 years of work experience $(n=65)$ and 19,8\% had 18-22 years of experience $(n=80) ; 16,1 \%$ were teacher candidates $(n=59), 68,6$ were teachers $(n=277)$ and $15,3 \%$ were $(n=62)$ expert teachers; $44,6 \%$ were teaching science $(n=180)$ and $55,4 \%$ were teaching $(n=224)$ social sciences; $78,7 \%$ were working in city centers $(\mathrm{n}=318)$ and $21,3 \%$ were working in small towns $(\mathrm{n}=86) ; 42,6 \%$ were working at Anatolian High Schools $(\mathrm{n}=172), 7,2 \%$ were working at social sciences high schools $(\mathrm{n}=29), 8,2 \%$ were working at science high schools $(\mathrm{n}=33)$ and $42,1 \%$ were working at vocational and technical high schools $(\mathrm{n}=170)$.

\subsection{Data Collection Tools}

The measurement tool used in the study, teachers' organizational commitment in educational institutions scale, was previously used by Celep (1998). It had two sections for teachers and students. The first section comprised conceptual questions aiming to describe teachers' demographics, while the second section included 32 items aiming to determine teachers' organizational commitment feelings. The data collection tool was graded as "Always (5), Often (4), Sometimes (3), Rarely (4), Almost never (1)". The interval of the tool was $4 / 5=.80$.

\subsection{Reliability and Validity of Data}

The construct validity of the tool was measured with exploratory factor analysis. Factor analysis is a statistical technique aiming to gather the variables measuring the same construct or quality and describe it with a few factors (Büyüköztürk, 2009:123). The suitability of the data for factor analysis was tested with Kaiser-Meyer-Olkin (KMO) and Barlett's tests. Bartlett Test $=4839,401$ and validity coefficient $\mathrm{KMO}=.913, \mathrm{p}=.000$. The minimum recommended $\mathrm{KMO}$ value for factor analysis to be performed on data was 0.60 (Pullant, 2001). Therefore, the data were deemed suitable for factor analysis. As a result of the first exploratory factor analysis on Teachers' Organizational Commitment Scale, one item with factor load value below 0.40 (item 23) and two items which appeared in more than one factor with a difference of .10 between them (items 8 and 15) (Büyüköztürk, 2009:125) were removed from the scale. At the end of the second factor analysis, two other items that appeared in multiple factors and had a difference below .10 (items 12 and 16) were also excluded. Ultimately the number of items in the scale went from 32 to 25 . The scale had four factors. The total variance explained by the four factors was 53\%. The Cronbach Alpha reliability value of the entire scale was .921. Following factor rotation, the first factor of the scale had ten items $(3,4,5,10,18,19,20,22,24,28)$ and its Cronbach Alpha reliability value was .84 . The load values of items in the first factor varied between 0.416-0.762. Factor two had four items $(1,2,6,7)$ and its Cronbach Alpha reliability value was .89 . The load values of items in factor two ranged between $0.787-0.872$. Factor three included five items $(9,11,14,17,21)$. The load values of items in factor three varied between $0.569-0.761$. The fourth factor had six items $(25,26,29,30,31,32)$. The Cronbach Alpha reliability value of this dimension was .78 . The load values of items in the fourth factor ranged between $0.475-0.710$. The factors were named by considering the contents of the items. The first factor was named "commitment to an advanced sense of duty", the second factor "commitment to school development", the third one "commitment to colleagues" and the final one "commitment to the teaching profession".

\subsection{Analysis Techniques}

The data were analyzed on the SPSS for Windows 21 package. Teachers' demographic characteristics (gender, marital status, age, professional experience, title, subject area, work place and place of duty) were identified through frequencies and percentages. The levels of teachers' feelings were identified with arithmetic means and standard deviations. Independent groups t-Test was performed to investigate whether a significant difference existed between the views of respondents with different gender, marital status, subject area and work place variables. In addition, one way analysis of variance (ANOVA) was used to explore whether the mean scores of the groups varied with age, title and years in the profession. The significance level of the tests was set at .05 .

\section{Findings}

This section includes findings on the subdimensions of the organizational commitment scale and teachers' comments. 1. The analysis results of the question "What are high school teachers' organizational commitment feelings in the subdimensions and the entire scale?" are shown in Table 1.

As can be seen in Table 1, high school teachers felt "always" committed only in the commitment to the teaching profession subdimension, while they "often" felt committed in other subdimensions and the entire scale. 
Table 1. Analysis results of the organizational commitment scale and its subdimensions

\begin{tabular}{lll}
\hline Subdimensions & $\mathrm{X}$ & $\mathrm{SS}$ \\
\hline 1. Commitment to an advanced sense of duty & 3,93 &, 68 \\
\hline 2. Commitment to colleagues & 3,78 & 1,02 \\
\hline 3. Commitment to the teaching profession & 3,85 &, 76 \\
\hline 4. Commitment to school development & 4,48 &, 53 \\
\hline 5. All of them & 4,02 &, 57 \\
\hline
\end{tabular}

2. The analysis results of the question "Do high school teachers' commitment to the development of their school, their colleagues, the teaching profession and an advanced sense of duty vary depending on variables such as gender, marital status, age, professional experience, title, subject area, work place and place of duty? " are given in Table 2.

Table 2. T-test results on teachers' commitment subdimensions based on gender, marital status, subject area and work place

\begin{tabular}{|c|c|c|c|c|c|c|c|c|}
\hline \multirow{2}{*}{ Subdimensions } & \multirow{2}{*}{ Variable } & \multirow{2}{*}{$\mathrm{N}$} & \multirow{2}{*}{$\mathrm{X}$} & \multirow{2}{*}{ SS } & \multicolumn{2}{|l|}{ Levene } & \multirow{2}{*}{$\mathrm{t}$} & \multirow{2}{*}{$\mathrm{p}$} \\
\hline & & & & & $\mathrm{F}$ & $\mathrm{p}$ & & \\
\hline \multirow{2}{*}{$\begin{array}{l}\text { 1. Commitment to advanced task } \\
\text { consciousness }\end{array}$} & Female & 170 & 4,01 &, 54 & \multirow{2}{*}{20,836} & \multirow{2}{*}{000} & \multirow{2}{*}{1,958} & \multirow{2}{*}{, 051} \\
\hline & Male & 234 & 3,87 &, 77 & & & & \\
\hline \multirow{2}{*}{ 2. Commitment to colleagues } & Female & 170 & 3,78 &, 79 & \multirow{2}{*}{,620 } & \multirow{2}{*}{, 432} & \multirow{2}{*}{$-1,638$} & \multirow{2}{*}{, 102} \\
\hline & Male & 234 & 3,90 &, 73 & & & & \\
\hline \multirow{2}{*}{$\begin{array}{l}\text { 3. Commitment to teaching } \\
\text { profession }\end{array}$} & Female & 170 & 4,52 & ,45 & \multirow{2}{*}{10,873} & \multirow{2}{*}{, 001} & \multirow{2}{*}{1,318} & \multirow{2}{*}{, 188} \\
\hline & Male & 234 & 4,45 &, 58 & & & & \\
\hline \multirow{2}{*}{$\begin{array}{l}\text { 4. Commitment to the } \\
\text { development of the school }\end{array}$} & Female & 170 & 3,67 & 1,01 & 156 & 603 & -1024 & 055 \\
\hline & Male & 234 & 3,86 & 1,03 & 156 & ,693 & $-1,924$ & , \\
\hline 5. All & Female & 170 & 4,03 &, 466 & & & & \\
\hline & Male & 234 & 4,02 & 63 & 10,000 &, 002 & ,242 & ,809 \\
\hline 1. Commitment to advanced task & Married & 297 & 3,90 &, 71 & & & & \\
\hline consciousness & Single & 107 & 4,01 &, 58 & 3,930 & ,048 & $-1,58 /$ &, 114 \\
\hline 2 Commitment to colleagues & Married & 297 & 3,88 & ,78 & & & & \\
\hline 2. Commitment to colleagues & Single & 107 & 3,77 &, 69 & 895 &, 345 & 1,446 &, 150 \\
\hline 3. Commitment to teaching & Married & 297 & 4,48 &, 53 & 040 & & & \\
\hline profession & Single & 107 & 4,48 &, 51 & ,940 & ,333 &, 147 &, 883 \\
\hline 4. Commitment to the & Married & 297 & 3,85 & 1,00 & 025 & 337 & 2366 & 018 \\
\hline development of the school & Single & 107 & 3,58 & 1,06 & ,925 &, 331 & 2,366 &, 018 \\
\hline 5. All & Married & 297 & 4,03 &, 59 & 1619 & 204 & 406 & 685 \\
\hline & Single & 107 & 4,01 &, 50 & 1,619 & ,204 & ,406 & ,685 \\
\hline 1. Commitment to advanced task & Science. & 180 & 3,98 & 65 & & & & \\
\hline $\begin{array}{l}\text { 1. Commitment to advanced task } \\
\text { consciousness }\end{array}$ & $\begin{array}{l}\text { Social } \\
\text { Sciences }\end{array}$ & 224 & 3,89 & ,71 &, 234 & ,629 & 1,213 & ,226 \\
\hline & Science. & 180 & 3,92 & ,71 & ,317 & 573 & 1,615 & , 107 \\
\hline 2. Commitment to colleagues & $\begin{array}{l}\text { Social } \\
\text { Sciences }\end{array}$ & 224 & 3,80 &, 79 & & & & \\
\hline 3 Commitment to teaching & Science. & 180 & 4,50 &, 50 & & & & \\
\hline $\begin{array}{l}\text { profession } \\
\text { promite to teacning }\end{array}$ & $\begin{array}{l}\text { Social } \\
\text { Sciences }\end{array}$ & 224 & 4,47 &, 54 & 1,220 & ,270 &, 740 & ,460 \\
\hline 4. $\quad$ Commitment to the & Science. & 180 & 3,92 & ,99 & & & & \\
\hline development of the school & $\begin{array}{l}\text { Social } \\
\text { Sciences }\end{array}$ & 224 & 3,67 & 1,03 & ,411 &, 522 & 2,397 &, 017 \\
\hline 5. All & Science. & 180 & 4,08 &, 53 & & & & \\
\hline & $\begin{array}{l}\text { Social } \\
\text { Sciences }\end{array}$ & 224 & 3,98 &, 59 & ,405 &, 525 & 1,877 &, 061 \\
\hline 1. Commitment to advanced task & $\begin{array}{l}\text { Province } \\
\text { center }\end{array}$ & 318 & 3,90 & ,71 & 4,902 & ,027 & $-1,787$ & 076 \\
\hline consci & District center & 86 & 4,03 &, 54 & & & & \\
\hline 2. Commitment to colleagues & $\begin{array}{l}\text { Province } \\
\text { center }\end{array}$ & 318 & 3,89 & ,76 & 389 & .533 & 2,053 & .041 \\
\hline & District center & 86 & 3,70 & ,72 & & & & \\
\hline 3. Commitment to teaching & $\begin{array}{l}\text { Province } \\
\text { center }\end{array}$ & 318 & 4,49 &, 53 & 361 & 549 & 801 & 425 \\
\hline profe & District center & 86 & 4,44 &, 51 & & & & \\
\hline $\begin{array}{l}\text { 4. Commitment to } \\
\text { development of the school }\end{array}$ & $\begin{array}{l}\text { Province } \\
\text { center }\end{array}$ & 318 & 3,88 & 1,01 & 080 & 778 & 3.810 & 000 \\
\hline & District center & 86 & 3,41 & 1,00 & & & & \\
\hline 5. All & $\begin{array}{l}\text { Province } \\
\text { center }\end{array}$ & 318 & 4,04 &, 59 & 2.054 & 153 & 1.186 & 237 \\
\hline & District center & 86 & 3,97 &, 48 & & & & \\
\hline
\end{tabular}

As shown in Table 2, teachers' commitment to school development varied significantly based on the variable of marital status $(\mathrm{t}(404)=2,366, \mathrm{p}<.05)$. Married teachers' commitment to school development level $(\mathrm{X}=3,85)$ was more positive than that of single teachers $(X=3,58)$. In the same sub dimension $(t(404)=2,397, p<.05$ science teachers' commitment 
levels $(X=3,92)$ were more positive than those of social sciences teachers $(X=3,67)$. In the commitment to colleagues and to school development sub dimensions ( $\mathrm{t}(404)=2,053$ and $3,810, \mathrm{p}<.059)$, the commitment levels of teachers working in city centers respectively $(X=3,89)(X=3,88)$ were more positive than teachers working in small towns respectively ( $X=3,70)$ and $(X=3,41)$.

3. The analysis results of the question "Is there a significant relationship between the sub dimensions of the organizational commitment scale and high school teachers' gender, marital status, age, professional experience, title, subject area, work place and place of duty?" are given in Table 3.

Table 3. ANOVA results of teachers' commitment sub dimensions based on age, years in the profession, title and place of employment

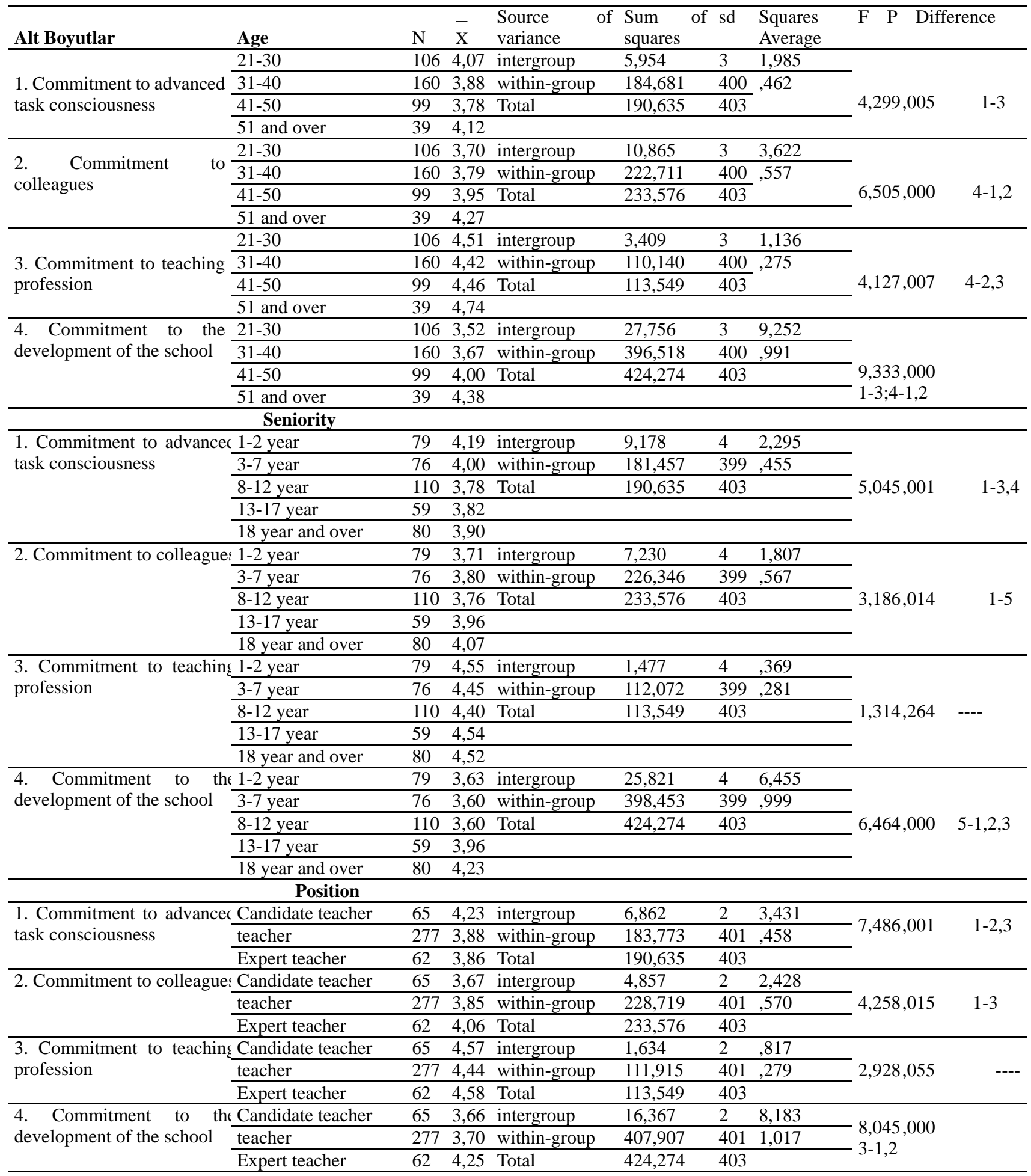




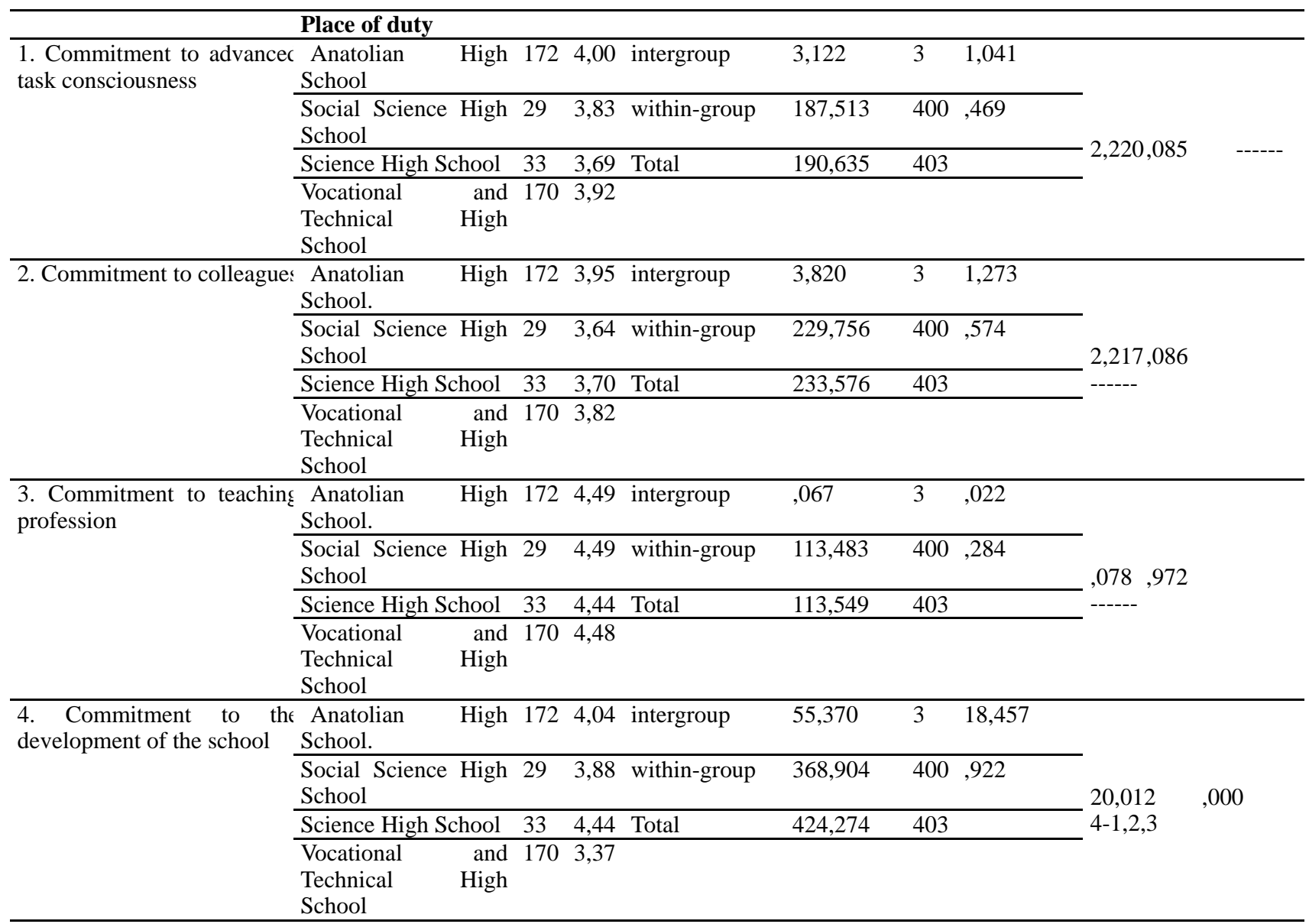

The analysis results with respect to age showed a significant difference in all sub dimensions $\mathrm{F}(3,400)=4,299 ; 6,505$; 4,$127 ; 9,333, p<.05$ respectively. The Scheffe test was performed to identify the groups causing significant differences, and its results showed that, in the commitment to an advanced sense of duty sub dimension, the scores of teachers aged 21-30 $(\bar{x}=4,07)$ were more positive than those aged 41-50 $(\bar{x}=3,78)$. Based on this finding, it may be stated that new teachers' will, passion and motivation were higher. In the commitment to school development sub dimension, teachers aged 21-30 $(\bar{x}=3,52)$ had more negative scores than those aged 41-50 $(\bar{x}=4,46)$. Considering that novice teachers do not have the experience and knowledge to contribute effectively to school development in the early years of their work life, they may not have the means to increase commitment. In the same sub dimension, the scores of teachers aged 51 and above $(\bar{x}=4,38)$ were more positive than those aged $21-30(\bar{x}=3,52)$ and $31-40(\bar{x}=3,67)$. As seniority also increases experience and expertise, teachers may contribute more to school development. In the commitment to colleagues sub dimension, teachers aged 51 and above $(\overline{\mathrm{X}}=4,27)$ had more positive scores than those aged $21-30(\overline{\mathrm{X}}$ $=3,70)$ or $31-40(\bar{x}=3,79)$. In the commitment to the teaching profession subdimension too, those aged 51 and above $(X=4,74)$ had more positive scores than those aged $31-40(\bar{x}=4,42)$ or $41-50(\bar{x}=4,46)$.

Scheffe test results revealed that in the commitment to an advanced sense of duty sub dimension, teachers with only 1-2 years of work experience $(X=4,19)$ had more positive scores than those with 8-12 $(\bar{x}=3,78)$ and 13-17 years of work experience $(\bar{x}=3,82)$. In the commitment to school development sub dimension, teachers with 18 and more years of work experience $(X=4,23)$ had more positive scores than those with $1-2(\bar{X}=3,63), 8-12(\bar{X}=3,60)$ or $13-17$ years $(\bar{X}$ $=3,60)$ of work experience. In the commitment to colleagues sub dimension, Bonferroni test results showed that teachers with $1-2$ years of work experience $(\bar{x}=3,71)$ had more positive scores than teachers with 18 years and more $(\bar{x}=4,07)$ work experience.

Regarding title, teacher candidates' scores in the commitment to an advanced sense of duty sub dimension $(\overline{\mathrm{X}}=4,23)$ were more positive than those of teachers $(\bar{x}=3,88)$ and expert teachers $(\bar{x}=3,86)$. This suggests that the title of expert teacher does not increase commitment to an advanced sense of duty. Therefore, the exams and evaluation criteria used in the allocation of this title should be revised and made more effective through new legislation (this revision took place while preparing this manuscript for publication, and announced in the Official Gazzette dated 09/06/2017 and numbered 30091). However, expert teachers are given little value at schools and there is no legislation to differentiate them from other teachers, thus preventing them from viewing the title as important. In the commitment to school development sub 
dimension, expert teachers' scores $(\overline{\mathrm{x}}=4,25)$ were more positive than those of teacher candidates $(\overline{\mathrm{x}}=3,66)$ and practicing teachers $(\overline{\mathrm{x}}=3,70)$. Expert teachers feel more commitment to developing their schools. In the commitment to colleagues sub dimension, expert teachers' scores $(\bar{x}=4,06)$ were more positive than those of candidate teachers $(\bar{x}$ $=3,67)$. The Bonferroni test results concerning place of employment showed that, in the commitment to school development subdimension, the scores of vocational and technical high school teachers $(\bar{x}=3,37)$ were lower than those of Anatolian High Schools $(\bar{x}=4,04)$, social sciences $(\bar{x}=3,88)$ and science high school teachers' $(\bar{x}=4,44)$ scores. It may be stated that vocational and technical high school teachers were not satisfied with their schools.

4. The analysis results of the question "What is the correlation between high school teachers' organizational commitment scale subdimensions and other variables?" are shown in Table 4.

Table 4. Correlation Between Variables

\begin{tabular}{|c|c|c|c|c|c|c|c|c|c|c|c|c|c|}
\hline & & $\frac{1}{1}$ & $\overline{22}$ & 3 & 4 & 5 & 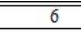 & $\overline{77}$ & 8 & 9 & 10 & 11 & 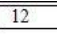 \\
\hline 1. Marital status & $\begin{array}{l}\text { Pearson Correlation } \\
\text { Sig. (2-tailed) }\end{array}$ & $\begin{array}{r}1 \\
404\end{array}$ & & & & & & & & & & & \\
\hline 2. Age & $\begin{array}{l}\text { Pearson Correlation } \\
\text { Sig. (2-tailed) }\end{array}$ & $\begin{array}{r}-, 428 * * \\
, 000\end{array}$ & 1 & & & & & & & & & & \\
\hline 3. Seniority. & $\begin{array}{l}\text { Pearson Correlation } \\
\text { Sig. (2-tailed) }\end{array}$ & & $\begin{array}{r}848 * \\
.0400 \\
.004\end{array}$ & $\begin{array}{r}1 \\
404\end{array}$ & & & & & & & & & \\
\hline 4. Position & $\begin{array}{l}\text { Pearson Correlation } \\
\text { Sig. (2-tailed) }\end{array}$ & $\begin{array}{r}-332^{* *} \\
.000 \\
404\end{array}$ & $\begin{array}{r}.573 * \\
.000 \\
404\end{array}$ & $\begin{aligned} &+04 \\
&, 700^{* * *} \\
&, 000 \\
& 404\end{aligned}$ & $\begin{array}{r}1 \\
404\end{array}$ & & & & & & & & \\
\hline 5. Branch & $\begin{array}{l}\text { Pearson Correlation } \\
\text { Sig. (2-tailed) }\end{array}$ & $\begin{array}{l}4075 \\
.075 \\
, 131 \\
404\end{array}$ & $\begin{array}{l}404 \\
-, 066 \\
, 183 \\
404\end{array}$ & $\begin{aligned} & 04 \\
&-, 114^{*} \\
& .022 \\
& 404\end{aligned}$ & $\begin{array}{l}.044 \\
.041 \\
.406 \\
444\end{array}$ & & & & & & & & \\
\hline 6. Work Place & $\begin{array}{l}\text { Pearson Correlation } \\
\text { Sig. (2-tailed) } \\
\text { N }\end{array}$ & $\begin{array}{r}, 277^{* *} \\
\quad, 000 \\
404\end{array}$ & $\begin{array}{r}-372^{* *} \\
.000 \\
404\end{array}$ & $\begin{array}{r}-354^{* *} \\
.000 \\
404\end{array}$ & $\begin{array}{r}-176^{* * *} \\
\quad 000 \\
404\end{array}$ & $\begin{array}{l}.027 \\
.572 \\
404\end{array}$ & $\begin{array}{r}1 \\
404\end{array}$ & & & & & & \\
\hline 7. Place of duty & $\begin{array}{l}\text { Pearson Correlation } \\
\text { Sig. (2-tailed) } \\
\text { N }\end{array}$ & $\begin{array}{l}.035 \\
.480 \\
404\end{array}$ & $\begin{array}{r}-, 094 \\
, 058 \\
404\end{array}$ & $\begin{array}{r}-, 070 \\
, 159 \\
404\end{array}$ & $\begin{array}{r}-.059 \\
.240 \\
404\end{array}$ & $\begin{array}{l}-.062 \\
.211 \\
404\end{array}$ & $\begin{array}{l}.049 \\
.329 \\
404\end{array}$ & $\begin{array}{r}1 \\
404\end{array}$ & & & & & \\
\hline 8. Commitment to advanced task consciousness & $\begin{array}{l}\text { Pearson Correlation } \\
\text { Sig. (2-tailed) } \\
\mathrm{N}\end{array}$ & $\begin{array}{l}.072 \\
.149 \\
404\end{array}$ & $\begin{array}{r}-, 059 \\
, 237 \\
404\end{array}$ & $\begin{array}{r}-, 1511^{* *} \\
.002 \\
404\end{array}$ & $\begin{array}{r}., 151^{* * *} \\
.002 \\
404\end{array}$ & $\begin{array}{r}-060 \\
.230 \\
404\end{array}$ & $\begin{array}{l}.076 \\
.126 \\
404\end{array}$ & $\begin{array}{l}-.059 \\
237 \\
404\end{array}$ & $\begin{array}{r}1 \\
404\end{array}$ & & & & \\
\hline 9. Commitment to the development of the school & $\begin{array}{l}\text { Pearson Correlation } \\
\text { Sig. } \quad \text { (2-tailed) } \\
\text { N }\end{array}$ & $\begin{array}{r}-, 117^{*} \\
, 018 \\
404\end{array}$ & $\begin{array}{r}.249 * * \\
.000 \\
404\end{array}$ & $\begin{aligned} .210^{* * *} \\
.000 \\
404\end{aligned}$ & $\begin{aligned} &, 159 * * \\
& .001 \\
& 404\end{aligned}$ & $\begin{array}{r}-, 119^{*} \\
.017 \\
404\end{array}$ & $\begin{aligned}-, 187 * * \\
.000 \\
404\end{aligned}$ & $\begin{array}{r}-, 283 * * \\
.000 \\
404\end{array}$ & $\begin{array}{r}, 438^{* * *} \\
.000 \\
404\end{array}$ & $\begin{array}{r}1 \\
404\end{array}$ & & & \\
\hline 10. Commitment to colleagues & $\begin{array}{lr}\text { Pearson } & \text { Correlation } \\
\text { Sig. } & (2 \text {-tailed }) \\
\mathrm{N} & \end{array}$ & $\begin{array}{l}-.068 \\
.174 \\
404\end{array}$ & $\begin{array}{r}.205^{* * *} \\
.000 \\
404\end{array}$ & $\begin{aligned} & 159^{* * *} \\
& .001 \\
& 404\end{aligned}$ & $\begin{aligned} .144^{* * *} \\
.004 \\
404\end{aligned}$ & $\begin{array}{r}-, 079 \\
.111 \\
404\end{array}$ & $\begin{array}{l}-, 102^{*} \\
.041 \\
404\end{array}$ & $\begin{array}{r}-.074 \\
.138 \\
404\end{array}$ & $\begin{array}{r}.536 * * \\
.000 \\
404\end{array}$ & $\begin{aligned} & 500^{* *} \\
& .000 \\
& 404\end{aligned}$ & $\begin{array}{r}1 \\
404\end{array}$ & & \\
\hline 11. Commitment to teaching profession & $\begin{array}{l}\text { Pearson Correlation } \\
\text { Sig. (2-tailed) } \\
\text { N }\end{array}$ & $\begin{array}{r}-.007 \\
.886 \\
404\end{array}$ & $\begin{array}{l}.071 \\
.152 \\
404\end{array}$ & $\begin{array}{l}.005 \\
.920 \\
404\end{array}$ & $\begin{array}{l}.005 \\
.9016 \\
404\end{array}$ & $\begin{array}{r}-, 037 \\
, 463 \\
404\end{array}$ & $\begin{array}{r}-, 039 \\
.432 \\
404\end{array}$ & $\begin{array}{r}-.013 \\
.788 \\
404\end{array}$ & $\begin{array}{r}, 576 * * \\
.000 \\
404\end{array}$ & $\begin{array}{r}384^{* *} \\
, 000 \\
404\end{array}$ & $\begin{array}{r}.458^{* * *} \\
.000 \\
404\end{array}$ & $\begin{array}{r}1 \\
404\end{array}$ & \\
\hline 12. The whole scale & & & & & & & & & $\begin{array}{l}.879 \\
.800 \\
404\end{array}$ & $\begin{array}{l}.720 \\
.000 \\
404\end{array}$ & $\begin{array}{l}., 773 \\
.000 \\
404\end{array}$ & $\begin{array}{l}.733 \\
.000 \\
404\end{array}$ & $\begin{array}{r}1 \\
404\end{array}$ \\
\hline
\end{tabular}

Table 4 shows a moderate, negative and significant relationship between teachers' age, years in the profession, titles and their marital status. There is also a weak, positive and significant relationship between work place and marital status. A weak, negative and significant relationship exists between commitment to school development and marital status. A high, positive and significant relationship is present between years in the profession and age. Title and age, on the other hand, have a moderate, positive and significant relationship between them. Work place and age are related with a moderate, negative and significant relationship. Commitment to school development and to colleagues was related to age with a weak, positive and significant relationship $(\mathrm{r}=0.24 ; \mathrm{r}=0,20, \mathrm{p}<.01)$. The correlation coefficient shows that as one gets older, their commitment to school development and colleagues both tend to increase. The determination coefficients $\left(r^{2}=0.058, r^{2}=0.04\right)$ suggest that $5,8 \%$ of the total variance in the commitment to school development behavior and $4 \%$ of the total variance in the commitment to colleagues behavior stem from age. A high, positive and significant relationship exists between years in the profession and title. On the other hand, there is a moderate, negative and significant relationship between work place and years in the profession. Commitment to school development and commitment to colleagues were linked to years in the profession with a weak, positive and significant relationship $(\mathrm{r}=0.21 ; \mathrm{r}=0,15, \mathrm{p}<.01)$. The correlation coefficient shows that as seniority increases, so do commitment to school development and to colleagues. Considering determination coefficients $\left(\mathrm{r}^{2}=0.045, \mathrm{r}^{2}=0.023\right), 4,5 \%$ of the total variance in commitment to school development behaviors and 2,3\% of the total variance in commitment to colleagues stem from years spent in the profession. There is a low, negative and significant relationship between commitment to the sense of advanced duty and years in the profession. The relationship between such commitment and work place and title is low, negative and significant. Commitment to school development and commitment to colleagues and title, on the other hand, are related with a weak, positive and significant relationship $(\mathrm{r}=0.16 ; \mathrm{r}=0,15, \mathrm{p}<.01)$. Correlation coefficients show that as title increases, commitment to school development and commitment to colleagues also increase. Determination coefficients $\left(\mathrm{r}^{2}=0.025, \mathrm{r}^{2}=0.022\right)$ reveal that $2,5 \%$ of the total variance in commitment to school development behaviors and $2,2 \%$ of the total variance in commitment to colleagues behaviors stem from title. A weak, negative and significant 
relationship exists between subject area and commitment to school development; work place and commitment to school development and commitment to colleagues; and place of employment and commitment to school development. A high, positive and significant relationship emerged between the subdimensions and the entire scale $(r=0.87, r=0.72, r=0.77$ and $\mathrm{r}=0.73$, respectively), and a moderate, positive and significant relationship among the subdimensions.

\section{Results, Conclusions and Recommendations}

The study explored the commitment feelings of high school teachers with respect to age, gender, years in the profession, title, subject area, and work place. The findings of the study are discussed here with reference to the existing literature. While high school teachers stated they were "always" committed to the teaching profession, they stated to be "often" committed in the other subdimensions. In the commitment to school development subdimension, there was a difference in favor of married teachers.

Artun's (2008) study showed that married and single teachers' organizational commitment scale scores did not vary. Ekinci and Yildirım (2015) also concluded in their study that secondary teachers' multidimensional organizational commitment levels did not vary based on their marital status. These results contradict those of the present study. In the commitment to school development subdimension, science teachers' commitment levels were higher than those of social sciences teachers. Kizıl's (2014) study showed that class teachers' organizational commitment scores were higher than those of science and mathematics teachers. Social sciences teachers' commitment to the team subdimension scores were higher than those of others.

In the commitment to colleagues and commitment to school development subdimensions, commitment levels of teachers in city centers are higher than those in small towns. High school teachers' commitment to an advanced sense of duty is higher among those aged between 21-30 than those aged between 41-50. In the commitment to school development subdimension, 21-30 year-old teachers' commitment levels were lower than those of 41-50 year-old teachers. In the same subdimension, commitment levels of those aged 51 and above, were higher than those aged between 21-30 and 31-40. In the same subdimension, Cengiz, Turgut and Kabakçı (2014) showed that the scores of teachers in the 21-30 age group were more negative than those of teachers in the 31-40 age group. According to results obtained by Güner, 2006; Topaloğlu et al., 2008; Artun, 2008; Atar, 2009; G1c1, 2011; Kutlay, 2012; Arslan, 2013; and Cengiz, Turgut and Kabakçı 2014, age did not cause a signficant effect in the subdimensions. On the other hand, several other studies (Karagöz, 2008; Apak, 2009; Demirhan, 2010; Taşçı, 2011; Kurtbaş, 2011; Narman, 2012; Ekenci, 2012) did report a significant relationship. According to these data, school commitment increases when the age interval increases. This may indicate that teachers' seniority and experience increase with age, thus giving them more positive feelings about the profession.

In the commitment to colleagues subdimension, the commitment levels of teachers aged 51 and above were more positive than those aged between 21-30 or 31-40. In the commitment to the profession subdimension, the commitment levels of teachers aged 51 and above were higher than those aged between 31-40 or 41-50. According to Artun's (2008) results, those aged 41 and above had significantly higher organizational commitment scale mean scores than those aged 30 and below and those between 31-40 years. No significant difference exists between those aged 30 and below and those aged between 31-40 years. While some results are similar, others are different. Turhan, Demirli and Nazik (2012) concluded that class teachers aged 51 and over had higher commitment to the profession than class teachers in other age groups. Zöğ (2007) and Apak (2009) found that as teacher's age increased, so did their commitment levels.

In the commitment to an advanced sense of duty subdimension, those with 1-2 years of work experience have higher commitment levels than those with 8-12 years and 13-17 years of work experience. In the commitment to school development subdimension, the commitment levels of those who have been working for 18 years and more are higher than those with 1-2 years, 8-12 years and 13-17 years of work experience. In the commitment to colleagues subdimension, the commitment levels of those who have been working for 1-2 years are higher than those with 18 years or more of work experience. Artun (2008) found in his study that the school commitment mean scores of teachers who have been working for 21-25 years are higher than those with 1-5 years and 6-10 years of work experience. Considering commitment to the teaching profession, those with 21-25 years of work experience have higher mean scores than those with 1-5 years and 6-10 years of experience. In the commitment to the team subdimension, teachers who have been working for 21-25 years had higher mean scores than with 1-5 years, 6-10 years and 11-15 years of work experience. At the same time, those who have been working for 16-20 years have higher mean scores than those who have been working for 1-5 years. These results are not parallel to the ones obtained in the present study. Atar, 2009; Karagöz, 2008; Güner, 2006; Kutlay, 2012; Demirhan, 2010; Taşç1, 2011; Kurtbaş, 2011; Güçlü and Zaman, 2011; Yılmaz, 2009 reached results some of which corroborate and some of which contradict this study. Cengiz, Turgut and Kabakçı (2014) found no significant difference between individuals' commitment scores and the subdimensions based on years spent working. This result is in contradiction with the results of the present study. Topaloğlu, Koç and Yavuz (2008) 
concluded that new teachers' organizational commitment levels were higher than those of senior teachers. These results are both similar to and deviate from the present study.

As for title, in the commitment to an advanced sense of duty subdimension, teacher candidates' commitment levels are higher than those of teachers and expert teachers. Cengiz, Turgut and Kabakçı (2014) concluded that research assistants had higher "commitment to the profession" than instructors, lecturers, assistant professors, associate professors and professors. Boylu et al. (2007) found that professors had lower loyalty levels than research assistants. These results are similar to those of this study. In the commitment to school development subdimension, the scores of teacher candidates are more negative than those of practicing teachers. Cengiz, Turgut and Kabakçı (2014) found that research assistants had higher "commitment to school" than lecturers and professors, which contradicts with the results here.

In the commitment to school development subdimension, expert teachers' commitment levels are higher than those of teacher candidates and teachers. In the commitment to colleagues subdimension, expert teachers' commitment levels were higher than those of teacher candidates. Concerning place of employment, in the commitment to school development subdimension, vocational and technical high school teachers' commitment levels are lower than those of Anatolian, social sciences and science high school teachers. Ekinci and Yildırım (2015) reported that vocational and technical high school teachers have higher commitment to the teaching profession than teachers working at general high schools. These results are not similar to those obtained in this study. Korkmaz (2014) concluded that science high school teachers felt more emotional commitment. These results are similar.

Teachers stated that they are always committed to all of the items in the commitment to the teaching profession subdimension. Celep (1998) also found that teachers were strongly committed to the teaching profession. In the commitment to colleagues subdimension, they were often committed in all items. However, the highest arithmetic mean occurred in the item about enjoying spending time together between classes. This finding is in accord with Celep's (1998) results. In the commitment to school development subdimension, teachers stated to always be proud of their school and often feel the passion to work at their school, choose to work at their particular school even if there was a chance to work elsewhere, enjoy working at their school and feel their school is the best. In the commitment to an advanced sense of duty dimension, teachers always felt proud of the teaching profession and often agreed with the other items. The item with the lowest score was about teaching a different course to stay in the school. In Celep's (1998) study, $62.6 \%$ of the teachers responded to the same item by saying that, if their school did not offer a course in their subject area, they would rather teach at a different school instead of staying in the same one and teaching courses outside their subject area. These results are similar to the ones obtained here. There is a moderate, negative and significant relationship between teachers' ages, years in the profession, titles and their marital status. A high, positive and significant relationship exists between the subdimensions and the entire scale. Between subdimensions too, a moderate, positive and significant relationship exists.

Based on the results of the study, the following recommendations may be made:

1. In the commitment to an advanced sense of duty subdimension, teacher candidates' scores were more positive than those of teachers and expert teachers. This revealed that both practicing teachers and expert teachers had low commitment despite their titles. It would be beneficial to explore the reasons for this and make legal adjustments for teachers' careers.

2. Teachers report low levels of job satisfaction due to inadequate salaries. The Ministry of Education should take this into account and improve the payment system by basing it on multi-data teacher performance

\section{References}

Apak, E. G. A. (2009). The Relationships between Mobbing Actions and Organizational Commitment: A Research on Elementary School Teachers. Unpublished master's thesis, Marmara University Institute of Educational Sciences.

Arslan, F. (2013). Formator and Coordinator Relations of Transformative Leadership Styles and Commitment Levels of Physical Education Teachers Perceived by School Principals, Gazi University Educational Sciences Institute.

Artun, B. (2008). The effect of organizational commitment levels of Anatolian high school teachers on organizational change. Unpublished master's thesis, Yeditepe University Social Sciences Institute.

Atar, G. (2009). The Relationship Between the Organizational Commitment of Elementary School Teachers and Perceptions of Leadership Behaviors of the Principals. Master's thesis, Maltepe University, Institute of Social Sciences.

Balay, R. (2000). Organizational Commitment in Managers and Teachers. Ankara: Nobel Publication Distribution

Büyüköztürk, Ş. (2009). Scientific Research Methods (4th Edition). Ankara: Pegem Academy

Celep, C. (1998). Organizational Commitment of Teachers in Educational Organizations. Journal of Education and 
Science, 22(108), 56-62.

Celep, C. (2000). Organizational Commitment and Teachers in Education. Ankara: Anı Publishing.

Cengiz, R., Turgut, M., \& Kabakçı, A. C. (2014). Determination of the Level of Commitment of Teaching Staff of High school of Physical Education and Sports, International Journal of Science Culture and Sport. Special Issue 1, 582-593. https://doi.org/10.14486/IJSCS128

Demirhan, G. (2010). The Relationship Between Educational Administrators 'Administrative Styles and Teachers' Degree of Commitment and Burnout. Graduate Thesis, Usak University, Institute of Educational Sciences.

Ekenci, Ö. (2012). The Relationship Between Illegal Behavior and Organizational Commitment of Secondary School Teachers. Graduate thesis, Necmettin Erbakan University Educational Sciences Institute.

Ekinci, Ö., \& Yıldırım, A. (2015). An Analysis of the Relationship Between Mobbing Behaviors and Organizational Commitment in Secondary Schools, International Journal of Educational Science, 2(5), 509-528.

Ergun, T. (1975). Concept of Commitment in International Organizations, Turkey Middle East Public Administration Publications, 8(4).

G1c1, A. (2011). Organizational Commitment Level of English Instructors Working at Foundation Universities Preparatory Schools in Istanbul. Master's thesis, Ylldz Technical University, Institute of Educational Sciences.

Güçlü, N., \& Zaman, O. (2011). The relationship between job satisfaction and organizational commitment of the guidance teachers assigned from outside the field. Turkish Education Sciences Magazine Summer, 9(3), 541-576.

Güner, H. (2006). Öğretmenlerin Adanmışlık Sorunu: İstanbul İli Örneğinde Bir Çalışma. Yüksek lisans tezi Marmara Üniversitesi Eğitim Bilimleri Enstitüsü.

Hoy, W. K., Tarter, C. J., \& Kottkamp, R. B. (1991). Open Schools, Healthy Schools, Newbury Park: Sage Production.

Kanungo, R. N. (1982). Measurement of job \& work involvement, Journal of Applied Psychology, 67(3), 341-349. https://doi.org/10.1037/0021-9010.67.3.341

Karagöz, A. (2008). The Relationship Between the Ethical Leadership Roles Perceived by Teachers of Primary and Secondary School Administrators and Organizational Commitment of Teachers (Bursa Case). Master's thesis, Yeditepe University, Institute of Social Sciences.

Karasar, N. (2009). Scientific Research Method. Concepts, Principles, Techniques (4th Edition). Ankara.

Kızıl, Ş. (2014). The Relationship Between Teachers' Emotional Intelligence and Organizational Commitment (Balikesir Case). Graduate thesis. Okan University Social Sciences Institute.

Korkmaz, H. (2014). An Examination of the Relationship Between Alienation Levels and Organizational Commitments of Teachers in Secondary Schools. Graduate thesis. Bahcesehir University Educational Sciences Institute.

Krejcie, R. V., \& Morgan, D. W. (1970). Educational and Psychological Measurement, 30, 607-610. https://doi.org/10.1177/001316447003000308

Kurtbaş, D. (2011). The Relationship Between Psychological Violence and Organizational Commitment Exposed by Academician A Research in Public and Foundation Universities. Graduate thesis, Gazi University, Institute of Educational Sciences.

Kutlay, Y. (2012). The Effect of Research Assistants' Organizational Commitment and Self-Sufficiency on Organizational Silence. Master Thesis, Isparta Süleyman Demirel University Social Sciences Institute.

Mowday, R. T., Steers, R. M., \& Porter, L. W. (1979). The measurement of organizational commitment, Journal of Vocational Behavior, 14(2), 224-247. https://doi.org/10.1016/0001-8791(79)90072-1

Narman, A. (2012). An Analysis of Teachers' Relations Between Organizational Trust and Organizational Commitment (Ümraniye District Example), M.Sc. Thesis, Istanbul Yeditepe University Social Sciences Institute.

Taşç1, Ö. (2011). The Relationship Between Perceptions of Elementary School Teachers' Impacts of School Administrators in Decision Making and Their Organizational Commitment. Graduate thesis, Yeditepe University Social Sciences Institute.

Topaloğlu, M., Koç, H., \& Yavuz, E. (2008). Analysis of Organizational Commitment of Teachers in terms of Some Basic Factors, Public-Business Journal, 9(4), 1-19.

Turhan, M., Demirli, C., \& Nazik, G. (2012). Factors Affecting the Level of Teacher 's Commitment to Occupation: The Case of Elazig. Istanbul Commerce University Journal of Social Sciences, 11(21), 179-192. 
Yılmaz, E. (2009). An Analysis of Organizational Commitment of Primary School Teachers in Terms of Job Satisfaction and Organizational Creativity in Schools. Primary Education Online, 8(2), 476-484.

Zöğ, H. (2007). The Relationship Between Organizational Commitment and Job Satisfaction of Elementary School Teachers in Istanbul. Unpublished Master's Thesis, Yıldız Technical University Institute of Social Sciences.

\section{Copyrights}

Copyright for this article is retained by the author(s), with first publication rights granted to the journal.

This is an open-access article distributed under the terms and conditions of the Creative Commons Attribution license which permits unrestricted use, distribution, and reproduction in any medium, provided the original work is properly cited. 